the integral being extended over the whole area of the glacier. $p_{0}$ must be equal to the weighted mean of $\frac{1}{2}(p+a)$ if the glacier is in equilibrium. This is possible in the case shown in Fig. $\mathbf{I}$, for the curve $\frac{1}{2}(p+a)$ is roughly a straight line except at its ends, where the weight is negligible, but in the case shown in Fig. 2 (p. $5 \mathrm{ro}), p_{0}=a_{0}$ is certainly less than the weighted mean of $\frac{1}{2}(p+a)$, even if the glacier is in equilibrium.

That the glacier is in balance can only be seen on curves of $p \cdot \frac{d S}{d z}$ and $a \cdot \frac{d S}{d z}$ as functions of $z$ (Fig. 3, p. 510). The areas between the curves and the z-axis represent the total ablation and accumulation of the glacier. If the glacier is in equilibrium the two shaded areas in Fig. 3 must be equal, and will both be equal to the amount of snow and ice crossing a vertical surface through the firn line in one year.

It would be of great interest to have further data on the accumulation and ablation at different heights.

Clasificador 95
Santiago (Chile)
7 July 1954

L. LliBoutRY

\title{
COMMENTS ON PROFESSOR LLIBOUTRY'S LETTER
}

By R. Finsterwalder

(Technische Hochschule, Munich)

THE data upon precipitation $p$ and especially ablation $a$ in glaciated regions have so far been rather poor. The parabola with a maximum in the height where the ablation is nearly zero is an approximation for the superposition $p-a$ of the precipitation and ablation curves. This parabola has proved true to a certain extent in the Eastern Alps for precipitation ${ }^{1}$ and also ablation measurements by our calculations of the height $z_{0}$ of the snow line. The method used by myself for fixing the height $z_{0}$ does not depend absolutely on this parabola as I have mentioned on page 3 Io, Vol. 2, No. I5, of this foumal. But if it is possible to draw a parabola the calculation of the height of the snow line is very easy and quick. ${ }^{2}$

It is certain that the shapes of the curves $p-a$ for precipitation and ablation can vary in the way Lliboutry explains in his interesting letter. The shape can be a parabola as in Fig. I or nearly a straight line as in Fig. 2 or a curve of higher order. For fixing the height of snow line by the formula (5) on page 310 of my paper it is only necessary to shift the curve parallel to itself in the direction of the $z$-axis until $\Sigma f . a$, or in the writing of Lliboutry $\int(p-a) d S$, is zero. The fixing of the height $z_{0}$ of the snow line becomes more accurate the larger is the angle by which the curve $p-a$ cuts the $z$-axis.

The method shown by Illiboutry in Fig. 3 for fixing $z_{0}$ is very interesting. By shifting the two curves $p$ and $a$ in the direction of the $z$-axis one can obtain equality in the two shaded areas. In practice it would be necessary to draw very accurately in order to obtain a sufficiently accurate result by this graphic method.

I agree with Lliboutry also with respect to his closing remark. It would be very useful to obtain more data about the variation of accumulation and ablation with height.

\section{R E F E R E N C E S}

I. Koch, K., and Reichel, E. Verteilung und jährlicher Gang der Niederschläge in den Alpen. Veröffentlichungen der Preussischen Meteorologischen Instituts, No. 374, Abh. Bd. 9, No. 6. Berlin, 1930.

2. See the calculated examples in Zeitschrift für Gletscherkunde und Glazialgeologie, Bd. 9, Ht. 2, 1953, p. $228-29$.

\section{The Editor,}

The Fournal of Glaciology

SIR,

The Depth of Crevasses

The discussion on crevasse depths in the Fournal of Glaciology, Vol. 2, No. 15, 1954, p. 339, leaves me in some doubt whether crevasses in temperate glaciers cannot exceed $30 \mathrm{~m}$. in depth. On the Ebnefluhfirn in the Bernese Alps, at a height of about $3700 \mathrm{~m}$., I once pulled a man from a snow 
bridge in a crevasse at a depth of $28 \mathrm{~m}$. below the surface level. He had crashed through two higher snow bridges to land on one which spanned the crevasse where it was still wide open. Miraculously he was not injured. As he was in the crevasse for over two hours his eyes must have become well adapted. He stated that the open crevasse continued to a considerable depth below the snow bridge, and this was confirmed by the time taken by snowballs to fall to the bottom. This crevasse must have reached at least the maximum depth of $120 \mathrm{ft} .(36.5 \mathrm{~m}$.) mentioned by Mr. Miller.

The pronounced bulging claimed by Dr. Nye for walls exceeding $34 \mathrm{~m}$. would apply not only to crevasses but to all ice walls. Glacier fronts in Greenland have often been found to reach twice, and occasionally three times, that height above the fjord level, but no marked bulging near the water level has been observed (see, for instance, E. Sorge, Umiamako- und Rinkgletscher, Universal-GrönlandExpedition 1932). It may be objected that, due to calving, the ice walls near the front of the glacier are changing too rapidly to allow marked bulging. But there are in the Arctic, as in the Antarctic, great numbers of stranded icebergs with walls considerably higher than $30 \mathrm{~m}$. above the water, for instance on Jakobshavn Iceberg Bank. They often remain in the same position for many months, and occasionally for more than a year. I do not know of any observations which show that they bulge markedly under their own weight. These icebergs generally derive, at least in the Arctic, from low-lying glacier tongues whose surfaces melt to a depth of several metres every year. As much of this melt water infiltrates, and a considerable fraction of it transfers its heat of fusion to the ice by freezing, the temperature of most of these icebergs cannot be considerably, if at all, below freezing point (Expéditions Polaires Francaises, Serie Scientifique, No. 10, 1949 [1950], p. 30). The absence of yielding, therefore, cannot be attributed to a low temperature.

But it should be noted that according to Dr. E. Orowan (Fournal of Glaciology, Vol. I, No. 5, I 949, p. 235) the critical height of 10 to $30 \mathrm{~m}$. applies only to ice columns with a height greater than their width, and not to ice slabs with horizontal dimensions comparable with their height. Therefore only the height of seracs or the depth of crevasses in a heavily dissected area would be limited in this way; more widely spaced crevasses, such as are generally found in the névé area or the walls of compact icebergs or stagnant glaciers, could exceed $30 \mathrm{~m}$. in height even if their temperature were at freezing point.

University of Melbourne,

Dept. of Meteorology

I7 May 1954

Fritz LOEWE

\title{
COMMENTS ON DR. LOEWE'S LETTER AND NOTES ON CREVASSES
}

\author{
By Dr. J. F. Nye \\ (University of Bristol)
}

Dr. LoEwE's letter is a stimulus to improve our theories. The present theory of the depth of crevasses is so rudimentary that one should not expect more than a rough agreement with experience. Orowan and Ward put forward a simple theory ${ }^{1}$ which connected the maximum depth of crevasses, $d$, with the "yield stress" of ice. If the yield stress of ice in compression is taken to be 2 bars (approximately $\left.2 \mathrm{~kg} . / \mathrm{cm} .{ }^{2}\right), d$ is calculated as $20 \mathrm{~m}$. The calculation is successful in that it shows how plasticity theory can give a result which is in general quantitative agreement with observation. But the result cannot be regarded as anything more than a first approximation, because the calculation takes as its model not a crevasse in a flowing glacier, but a tall, slender and stationary column of ice.

The last paragraph of Dr. Loewe's letter seems to spring from a misunderstanding. If Orowan's tall, slender column model is extended so that only one horizontal dimension is infinite, the stresses and critical height do not change by more than is per cent. This follows from the well-known relation in plasticity between the yield stress in plane stress and in plane strain. Orowan's second model (which he applied to an ice cap) refers to a case where both horizontal dimensions are large; it is therefore not relevant to the crevasse problem.

The following calculation on crevasse depths gives the possibility of a more detailed comparison between theory and experiment than has been possible hitherto. Let us first assume that transverse 